\title{
Charging electric cars as a way to increase the use of energy produced from RES
}

https://doi.org/10.1515/eng-2020-0009

Received Oct 30, 2019; accepted Dec 24, 2019

\begin{abstract}
The article contains an analysis of charging electric cars as a way to increase the use of energy produced from a photovoltaic system. A photovoltaic system is described, consisting of two micro installations, with a power output of up to $40 \mathrm{kWp}$ each, supplying two sectors of the building of the Lublin Science and Technology Park. An internet platform for monitoring the operation of a photovoltaic system is presented. Next, an innovative system for monitoring, consumption and production analysis of electric energy in individual building sectors is described. A surplus of energy produced in one of the sectors was found. It was proposed that this excess energy would be used to charge electric vehicles. An analysis of the surplus power generated by the photovoltaic system in excess of the energy consumed by the building sector was used to determine the power available to the wall charger. The surplus of energy produced was used for calculations related to the amount of charging the electric vehicle required and the cost of traveling $100 \mathrm{~km}$. Charging an electric car not only provides a faster return on investment in the installation, but also presents drivers with a very ecological and economical transport solution.
\end{abstract}

Keywords: photovoltaic system, electricity production, charging of electric cars, wallbox charger, electric vehicle autonomy

\footnotetext{
${ }^{\star}$ Corresponding Author: Arkadiusz Małek: University of Economics and Innovation in Lublin, Department of Transportation and Informatics, Projektowa 4, 20-209 Lublin, Poland;

Email: arkadiusz.malek@wsei.lublin.pl

Jacek Caban: University of Life Sciences in Lublin, Faculty of Production Engineering, Głęboka 28, 20-612 Lublin, Poland;

Email: jacek.caban@up.lublin.pl

Łukasz Wojciechowski: Lublin University of Technology, Department of Mechanical Engineering, Nadbystrzycka 36, 20-618 Lublin, Poland; Email: l.wojciechowski@pollub.pl
}

\section{Introduction}

At present, subjects related to the design, construction and control of energy produced by photovoltaic systems are being eagerly studied by scientists from various scientific disciplines. This is due to the mechatronic nature of photovoltaic farms. They contain mechanical components and electronic controls based on measured and processed signals. Photovoltaic systems are devices of the Internet of Things capable of communicating with each other and with the buildings and the cars they supply.

Security sensitive services within critical infrastructures have specific requirements regarding availability of the network architecture [1]. Such infrastructure also includes transport and traffic, as well as information technologies and telecommunications.

Energy intensity of transport is a current topic around the world [2]. An emphasis on technologies ensuring clean environment is greatly demanded of modern cities, where the significant growth of transportation results in increased pollution and other serious environmental problems [3]. Global warming and air pollution are largely caused by GHG [4]. They are emitted by many anthropological activities like industrial and transport activities [5]. The producers of vehicles for public transport introduced electric and hybrid vehicles that minimize the use of combustion engines and its negative effects on environment by integrating them with electric motors [6].

Photovoltaics is one of the main global trends related to obtaining energy from renewable energy sources (RES). It is an estimated billion-dollar market which presents an alternative to obtaining energy from fossil sources [7]. It turns out that this trend may be combined with other trends, such as Electromobility. Electric cars, charged with electricity produced by photovoltaic systems, become completely zero-emission vehicles. In addition, the increasing number of electric vehicles in Poland [8] and in the world will require substantial amounts of electricity to charge them.

Photovoltaic systems may be divided into stationary and mobile systems. The stationary ones are usually mounted on the roofs of buildings or on the ground. Spe-

๖ Open Access. (C) 2020 A. Matek et al., published by De Gruyter. (CC) BY This work is licensed under the Creative Commons Attribution 4.0 License 
cial ground structures are often created for the production of electricity and shadow generation for parked vehicles - so they called carports [8]. Having a source of electricity next to a parked vehicle, means that it may be used to charge parked electric vehicles. Photovoltaic systems have been mounted on various types of vehicles. First, public transport buses were used because of the availability of a large area for the installation of photovoltaic panels [9]. Researchers studied the subject of the safety of mobile photovoltaic systems and their productivity. Flexible photovoltaic panels can also be mounted on various body parts of passenger vehicles [10].

Regardless of the location of the photovoltaic system, an issue often raised by scientists and individual users are the economic aspects related to the return on investment from the system. Technical aspects related to their construction are also very important. We may also categorise photovoltaic systems according to the amount of power generated. In this respect Polish law distinguishes micro-installations with a power output of up to $40 \mathrm{kWp}$. They are usually sufficient to supply individual households and smaller public institutions generating electricity for their own needs. In this way they become prosumers, i.e. both producers and consumers of the energy produced. Researchers from various countries have been collecting information concerning energy use they base their forecasts on current energy consumption in households. Depending on the size of the photovoltaic system and the building's requirement for electricity, there may be a different degree of use of energy produced for own needs. If the amount of energy produced by the photovoltaic system is higher than the building's requirement, it is necessary to sell the surplus of produced energy for use in the power grid. The alternative is to accumulate the excess electricity produced in stationary or traction batteries for vehicles. Excess energy may also be used to produce pure hydrogen, which can then be converted into electricity and heat in hydrogen fuel cells.

A very important area of research and development for photovoltaic system components is material engineering, which provides innovative materials for the construction of photovoltaic systems and energy inverters. Currently, composite materials [11], metal nanofibers [12], polymers [13] and perovskites [14] are used in the construction of panels. Application of the nanotechnology in photovoltaics should be emphasized [15], especially the various functional nanofibers due to the high geometric potential of nanofibers [16-18]. Modern materials are characterized by increasing efficiency, lower price and a greater durability to weather conditions which may lead to a degradation in photovoltaic system performance [19]. Therefore, the mechanisms of degradation should be thoroughly understood in order to effectively counteract them [20].

One of the very popular and useful ways to research photovoltaic systems is to investigate their diagnostic systems. Intelligent algorithms allow for the quick and precise detection of irregularities in the operation of a photovoltaic system [21].

In order to effectively control the photovoltaic system itself and the use of the energy produced, it is necessary to make precise measurements with a high degree of accuracy. Scientists are still working on the evaluation of mathematical methods to characterize the electrical parameters of photovoltaic panels [2]. The relationships between the electrical parameters characterizing the photovoltaic system are very important [22]. Measurements are vital for managing the energy produced and its use in charging energy storage batteries [23]. The measured parameters are processed and used to optimize the system operation. The control algorithms developed should be thoroughly validated in real conditions [24]. Modern photovoltaic inverters and energy management systems are becoming increasingly advanced and have innovative functions related to the detection of the amount of dirt on the panels [25] and the generation of messages about the need to clean them [26, 27]. Short circuits in the installation are also automatically detected and precisely located [28]. Many systems have the ability to monitor the parameters of each panel using individual optimizers [29].

All managers of the photovoltaic systems has set themselves the goal of returning the money invested in its construction as soon as possible [30]. The way to achieve this aim is the total or maximum possible use of the energy produced for own needs. The goal of their research and applications could be charging an electric car as an effective way to increase the use of energy produced from renewable energy sources.

Many scientific studies include the development of infrastructure for charging electric vehicles and the growth of the electric vehicle market in various countries [31]. These studies are conducted as both experimental and simulation [32].

\section{Research object}

There is a ground photovoltaic system in front of the building of the Lublin Science and Technology Park (LSTP). It consists of 2 micro installations with a peak power output of up to $40 \mathrm{kWp}$ each, using polycrystalline photovoltaic panels. The system was launched at the end of November 
2018, the system is shown in Figure 1. LSTP received funding from the Lublin Agency for Enterprise Support for the construction of the system.

Both micro-installations were connected to two parts of the building and power various types of electrical devices. The first micro-installation powers Sector 4 of the building, in which most of the electricity supplies the servers of the Centre for Supervision over the Eastern Poland Broadband Network. The second microinstallation supplies Sector 5 of the building where the offices of the LSTP Board as well as the offices and laboratories of various tenants are located. The main consumers of electricity in this section are: lighting, air conditioning, office equipment and the equipment of low-power research laboratories.

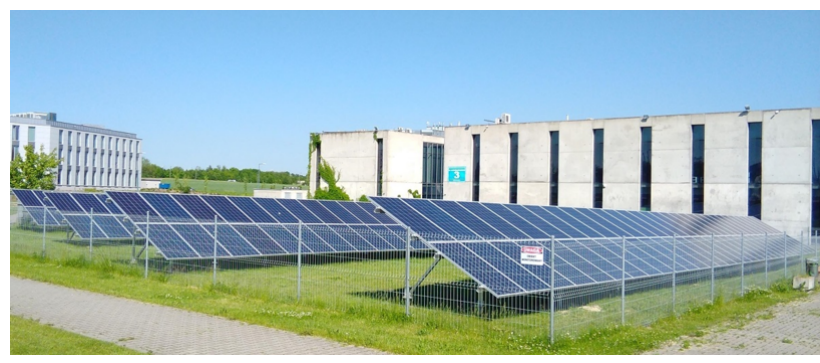

Figure 1: Photovoltaic plants in front of the building of the Lublin Science and Technology Park

\section{The requirement of the LSTP building for electricity}

The amount of energy drawn from the power grid and the surplus fed into it can be measured using a two-way electricity meter. OneMeter was used to automatically obtain data from electricity meters installed in LSTP Sectors 4 and 5. Two OneMeter Business devices were purchased and installed. The OneMeter measuring device, in the form of a beacone [34], works with bidirectional electricity meters on the LSTP Sectors 4 and 5. Then, via Bluetooth transmission, it transmits the measurement data obtained from the energy meter to the cloud. Data collected in the cloud can be displayed in the form of readable charts both on a PC and on a mobile device [33]. In July 2019, LSTP photovoltaic plant produced 11,7 MWh of electricity and production from both installations was very close to the 50:50 ratio.
From the Sector 4 measurement data, it appears that almost all the energy produced by 1 micro-installation is used for the LSTP building's own requirements (Figure 2). The surplus produced and sold to the power grid was only $527 \mathrm{kWh}$ compared to consumption $12740 \mathrm{kWh}$. Almost total use of energy produced for own needs is a method for quick return of money invested in the photovoltaic system.

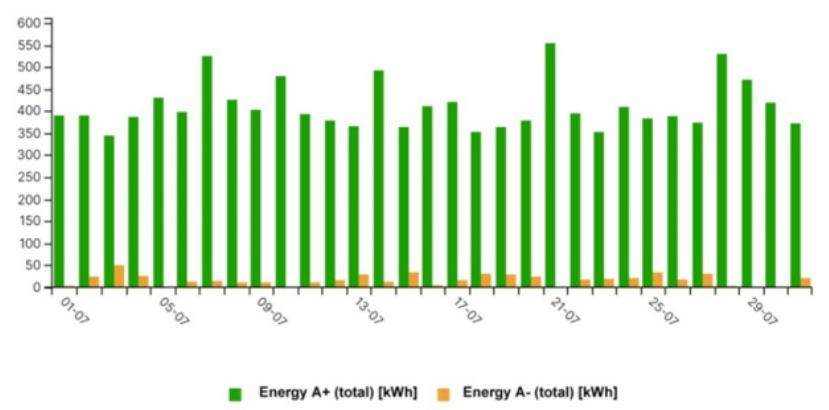

Figure 2: Graph of energy consumed $\left(A^{+}\right)$and donated $(A-)$ in Sector 4 LSTP in the month of July 2019

The situation in Sector 5 of LSTP appears to be worse as shown in Figure 3. Compared to Sector 4, there is a much lower daily energy consumption requirement and a much larger surplus of energy produced.

The surplus of the energy produced by the enterprises was resold to an energy seller at a very unfavorable price constituting less than $25 \%$ of the total purchase price (including distribution and sale). In practice this constitutes a 4-fold increase in the payback time in the case of a large ratio of surplus energy sold to the distributor. To counteract this situation, the option of connecting other Sectors to Sector 5 should be considered. However, the situation is complicated by the ownership structure and the current design of the electrical network throughout the building.

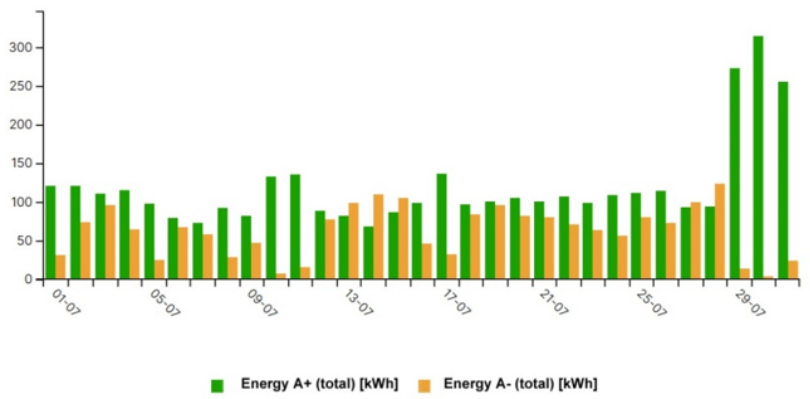

Figure 3: Graph of energy consumed $\left(A^{+}\right)$and donated $\left(A^{-}\right)$in Sector 5 LSTP in the month of July 2019 
Overview of consumption on weekdays (Figure 4) and on weekends (Figure 5) showed that the surplus of energy produced is much higher on non-working days. The amount of energy produced these days by the photovoltaic system was very similar and amounted to $446.1 \mathrm{kWh}$ and $439.0 \mathrm{kWh}$. The surplus energy was $70.8 \mathrm{kWh}$ and 123.2 kWh, respectively.

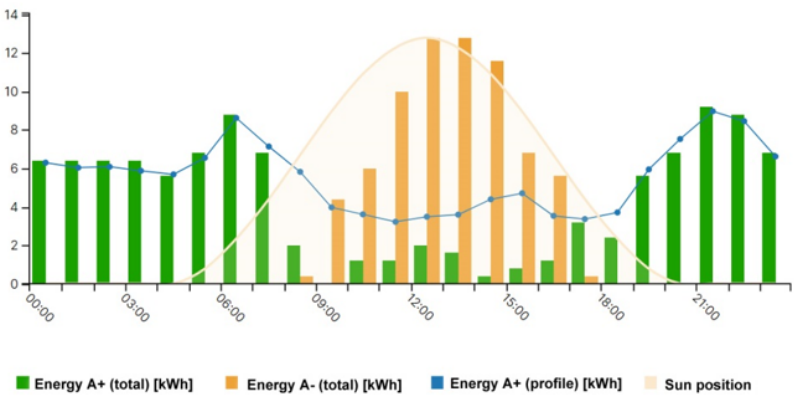

Figure 4: Graph of energy consumed $\left(\mathrm{A}^{+}\right)$and donated $(\mathrm{A}-)$ in Sector 5 LSTP on an example weekday

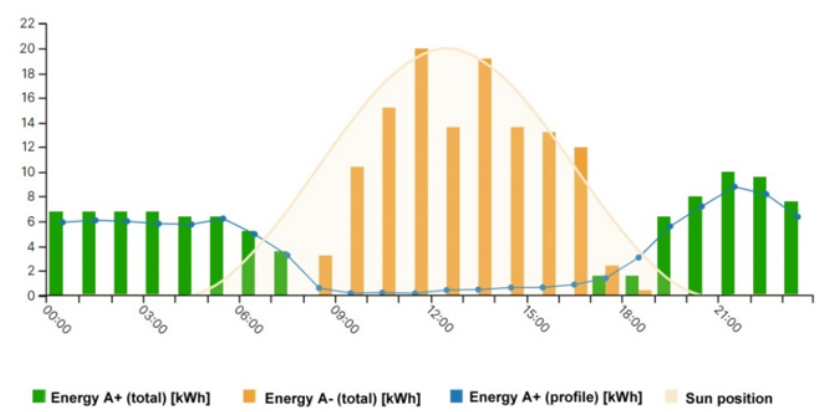

Figure 5: Graph of energy consumed (A+) and donated (A-) in Sector 5 LSTP on an example weekend day

The graph in Figure 6 shows the profile of active power consumed during the day. The minimum, maximum and average values are presented in 15-minute intervals. The profile clearly shows the night consumption values when the photovoltaic system is not working. During the day, the impact of energy produced by the micro-installation is visible, which during photovoltaic hours reduces the power consumed by Sector 5 to values close to zero. Maximum values occur on days of very low sunlight, when the power generated by the photovoltaic system is not able to cover the needs of Sector 5. Therefore, the maximum values in form users about the potential power consumption of the building without a photovoltaic system.

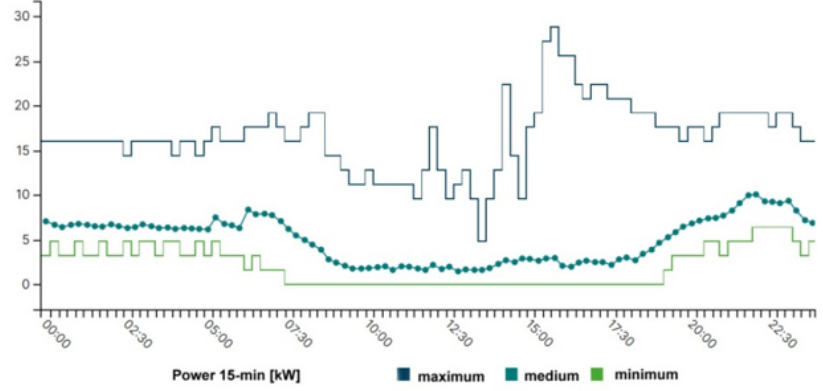

Figure 6: 15-minute profile of active power consumed in Sector 5 LSTP in the month of July 2019

\section{Charging electric cars from a photovoltaic system}

In sector 5 LSTP, a surplus of generated power and thus of produced energy was measured. Surplus power was generated on almost all days of the spring months and ranged from several to $25 \mathrm{~kW}$. Table 1 presents the values of energy consumed and returned to the power grid in various months of 2019. In individual months, the surplus of electricity produced was found to range from 1.5 to $2.6 \mathrm{MWh}$.

Table 1: Active energy consumed and energy given away in various months of 2019 year in Sector 5 LSTP

\begin{tabular}{ccc}
\hline $\begin{array}{c}\text { Month of } \\
2019\end{array}$ & $\begin{array}{c}\text { active energy consumed } \\
{[\mathrm{kWh}]}\end{array}$ & $\begin{array}{c}\text { energy given } \\
\text { away [kWh] }\end{array}$ \\
\hline April & 4043.0 & 1898.0 \\
May & 3305.6 & 2162.8 \\
June & 3038.4 & 2622.4 \\
July & 3682.4 & 1928.4 \\
August & 4848.8 & 1728.8 \\
September & 3680.8 & 1511.2 \\
\hline
\end{tabular}

These are significant amounts of energy that can significantly affect the payback time of an investment in a solar installation. The authors propose to use the excess energy produced to charge electric cars. An important challenge is to choose an electric car with the appropriate charging mode.

The purchase of an electric vehicle with an on-board three-phase charger with a maximum power of $22 \mathrm{~kW}$ was proposed to cater for the needs of LSTP. The power requirements of the on-board charger corresponds to the excess power produced by the photovoltaic system in sector 5 LSTP. Wall chargers are used to charge electric vehi- 
Table 2: Comparison of charging parameters and autonomy of electric vehicles

\begin{tabular}{lccccccc}
\hline & $\begin{array}{c}\text { Battery } \\
\text { capacity } \\
{[\mathrm{kWh}]}\end{array}$ & $\begin{array}{c}\text { Power of } \\
\text { on-board } \\
\text { charger }[\mathrm{kW}]\end{array}$ & $\begin{array}{c}\text { Time of full } \\
\text { charging }[\mathrm{h}]\end{array}$ & $\begin{array}{c}\text { Number of } \\
\text { full } \\
\text { chargings in } \\
\text { month }\end{array}$ & $\begin{array}{c}\text { Autonomy in } \\
\text { NEDC [km] }\end{array}$ & $\begin{array}{c}\text { Month total } \\
\text { autonomy } \\
{[\mathrm{km}]}\end{array}$ & $\begin{array}{c}\text { Cost of } \\
\text { driving } 100 \\
\mathrm{~km}[€]\end{array}$ \\
\hline $\begin{array}{l}\text { Nissan } \\
\text { Leaf II } \\
\text { Renault } \\
\text { Zoe }\end{array}$ & 40 & 6.6 & 7.5 & 50 & 378 & 18900 & 0.54 \\
\hline
\end{tabular}

cles. In fact, they are not chargers, but electricity consumption points. Their task is to provide three-phase alternating current to the vehicle's on-board charger using a Type 2 connector. Another very important function is communication with the powered vehicle through which it is possible to carry out controlled and safe charging. Communication mainly includes determining the state of readiness and current parameters required by the charged vehicle. Wallboxes very often have a blockade of access to energy using RFID cards. The more advanced ones have the ability to control the maximum power consumed and monitor via cloud storage all of the charging parameters. Based on such data, a report is generated concerning the charging record and it is possible to settle the costs of electricity consumed. The cost of such a device ranges from 1,000 to $2,000 €$.

An example of such a device is the Wallbox presented in Figure 7. It is described by the manufacturer as an intelligent, innovative semi-fast charger for $22 \mathrm{~kW}$ electric cars. Charger management is possible from the application level with the use of a mobile device. The application assists the user to manage energy consumption, the range of features available include:

- control of energy use with real-time monitoring,

- remote control (lock / unlock and output current),

- car charging planning and settings for specific tariffs,

- charging, energy consumption and cost statistics,

- application for iOS and Android.

The function of remotely controlling the current and output power at the same time may be used to optimize the consumption of surplus power from the photovoltaic system.

In order to justify the use of the surplus electricity generated to power electric vehicles, a comparison was made between two of the most common electric vehicles in Poland: Nissan Leaf and Renault Zoe (Table 2). Both of the vehicles have traction batteries with the same energy

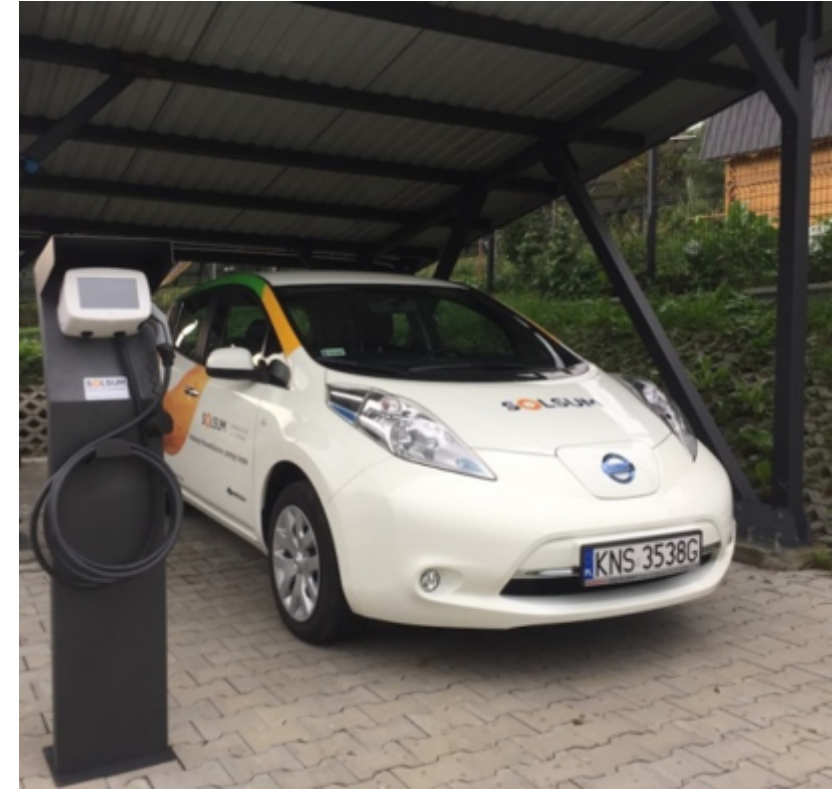

Figure 7: Wallbox with Nissan Leaf. Source: [35]

capacity and are sold at a similar price. $2 \mathrm{MWh}$ of electricity is available to charge the vehicles in question per month. We assume that the cost of the electricity is $41.92 €$ net / 1 MWh, which gives a total cost of $103.06 €$ gross / 2 MWh.

Table 2 presents that compared cars are characterised different power of the on-board charger. More powerful charger affects faster charging and greater use of surplus power and energy. An electric vehicle with less on-board charger power is not able to use all the surplus power.

The comparison shows that the Renault Zoe is a better solution for the needs of LSTP. The power of the $22 \mathrm{~kW}$ onboard charger would allow the owner to use almost all of the excess instantaneous power generated. On the other hand, the Nissan Leaf is available on the Polish market with only a $6.6 \mathrm{~kW}$ charger, which translates into a threefold longer charging time. With the current monthly overproduction of electricity, the electric vehicles which avail of this electricity could travel several thousand kilometres. 


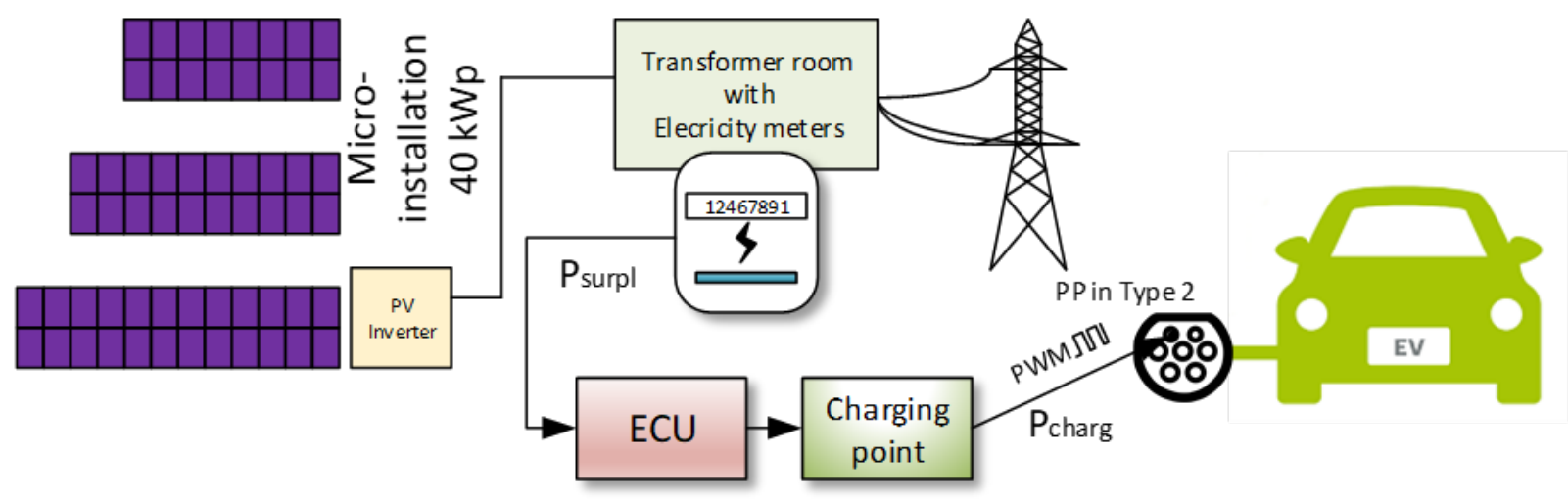

Figure 8: The conceptual diagram of the electronic control system

The authors also presented a calculation of the cost of driving $100 \mathrm{~km}$. These are very modest costs that would offset the high costs of purchasing electric vehicles.

\section{Electronic control system to management of the surplus power}

Figure 8 shows a conceptual diagram of the electronic control system for the surplus of power produced by the photovoltaic system. The control input is the instantaneous value of surplus of power that can be read from the electricity meter $\left(\mathrm{P}_{\text {surpl }}\right)$. This value is then used to determine the power of the charging point. Then the charging point sends information about the available power to the vehicle's on-board charger $\left(\mathrm{P}_{\text {charg }}\right)$. This is the control output from the Electronic Control Unit (ECU). This communication is done by means of a pilot pin in a Type 2 electrical connector using a signal in the form of a variable PWM (Pulse-Width Modulation).

The proposed control method is innovative. Is based on information about the surplus power produced by the photovoltaic system to control the power of the electric vehicle charger. This approach ensures that the surplus energy produced by the photovoltaic system is fully utilized. Unfortunately, the total charging time will be extended, as the charging process will not take place at maximum power. However, the costs of the charging process will be minimized due to the costs of energy consumed and given away the power grid.

\section{Conclusion}

A photovoltaic system consisting of two micro installations with a power output of up to $40 \mathrm{kWp}$ each was built to supply electricity to two sectors of the Lublin Science and Technology Park building. The manager of the photovoltaic system has set himself the goal of returning the money invested in its construction as soon as possible. The way to achieve this aim is the total or maximum possible use of the energy produced for own needs. Any other eventuality associated with the sale of the surplus energy would certainly extend the return on investment period. This is due to the method of paying electricity distributors and sellers which is unfavorable to the RES energy producer. The online platform presented for monitoring photovoltaic system operation is a very useful tool for monitoring performance and diagnosing the operational characteristics of the system. It was used to assess the power generated and the amount of electricity produced by the photovoltaic system. An innovative system for monitoring, analyzing consumption and production as well as the efficient use of electricity in individual building sectors produces a very wide range of possibilities. With its assistance, the surplus of energy produced was measured for one of the sectors. It was proposed that it should be used to charge electric vehicles. An analysis of the surplus power generated by the photovoltaic system over the energy consumed by the building sector (up to $25 \mathrm{~kW}$ ) was used to determine the power required by the wall charger. A $22 \mathrm{~kW}$ device was selected, which is a three-phase AC supply point for electric vehicles with on-board chargers. The monthly surplus of energy produced (amounting to $2 \mathrm{MWh}$ ) was used for calculations related to the number of full charges of the electric vehicle in question and the cost of driving it $100 \mathrm{~km}$. The calculations were made for two electric vehicles popular in Poland: Nissan Leaf and Renault Zoe. Charging an 
electric car is an effective way to increase the use of energy produced from renewable energy sources. It not only ensures a faster return on investment in the installation but also ensures that a very ecological and economical form of transport is used.

\section{References}

[1] Keil R, Krone D, Kremenova I, Madlenak R. Communications networks as base for mobility - trend development of network architectures. Communications - Scientific Letters of the University of Zilina. 2015;17(2):80-85.

[2] Aoun N, Bailek N. Evaluation of mathematical methods to characterize the electrical parameters of photovoltaic modules. Energy Conversion and Management. 2019;193:25-38.

[3] Barta D, Mruzek M, Kendra M, Kordos P, Krzywonos L. Using of non-conventional fuels in hybrid vehicle drives. Advances in Science and Technology Research Journal. 2016;32:240-247.

[4] Skrucany T, Kendra M, Stopka O, Milojević S, Figlus T, Csiszar C. Impact of the electric mobility implementation on the Greenhouse Gases production in Central European Countries. Sustainability. 2019;11(18):1-15.

[5] Lebkowski A. Studies of Energy Consumption by a City Bus Powered by a Hybrid Energy Storage System in Variable Road Conditions. Energies. 2019;12:951.

[6] Jorgensen K. Technologies for electric, hybrid and hydrogen vehicles: electricity from renewable energy sources in transport. Utilities Policy. 2008;16(2):72-79.

[7] Choudhary P, Srivastava RK. Sustainability perspectives - a review for photovoltaic photovoltaic trends and growth opportunities. Journal of Cleaner Production. 2019;227:589-612.

[8] Małek A, Kośko M, tusiak T. Urban logistics of small electric vehicle charged from a photovoltaic carport. The Archives of Automotive Engineering - Archiwum Motoryzacji. 2019;82(4):6577.

[9] Caban J, Zarajczyk J, Matek A. Possibilities of using electric drives in city buses. Proceeding of $23^{\text {rd }}$ International Scientific Conference Transport Means. 2019:543-547.

[10] Hai Vu N, Pham TT, Shin S. Flat concentrator photovoltaic system for automotive applications. Photovoltaic Energy. 2019;190:246254.

[11] Imbuluzqueta G, Yurrita N, Aizpurua J, Cano FJ, Zubillaga 0. Composite material with enhanced ultraviolet performance stability for photovoltaic modules. Photovoltaic Energy Materials and Photovoltaic Cells. 2019;200:Article 109947.

[12] Liu J, Jia D, Gardner JM, Johansson EMJ, Zhang X. Metal nanowire networks: Recent advances and challenges for new generation photovoltaics. Materials Today Energy. 2019;13:152-185.

[13] Tatsi E, Griffini G. Polymeric materials for photon management in photovoltaics. Photovoltaic Energy Materials and Photovoltaic Cells. 2019;196:43-56.

[14] Liu G, Kong L, Yang W, Mao H. Pressure engineering of photovoltaic perovskites. Materials Today. 2019;27:91-106.

[15] Ahmed OK, Bawa SM. The combined effect of nanofluid and reflective mirrors on the performance of photovoltaic/thermal solar collector. Thermal Science. 2019;2:573-587.
[16] Xie L, Lee JS, Jang Y. Organic Photovoltaics Utilizing a Polymer Nanofiber/Fullerene Interdigitated Bilayer Prepared by Sequential Solution Deposition. Journal Of Physical Chemistry C. 2016;24:12933-12940.

[17] Tian D, Li XX, He JH. Geometrical potential and nanofiber membrane's highly selective adsorption property. Adsorption Science \& Technology. 2019;37(5-6):367-388.

[18] Li XX, He JH. Nanoscale adhesion and attachment oscillation under the geometric potential. Part 1: The formation mechanism of nanofiber membrane in the electrospinning. Results In Physics. 2019;12:1405-1410.

[19] Katayama N, Osawa S, Matsumoto S, Nakano T, Sugiyama M. Degradation and fault diagnosis of photovoltaic cells using impedance spectroscopy. Photovoltaic Energy Materials and Photovoltaic Cells. 2019;194:130-136.

[20] Azizi A, Logerais PO, Omeiri A. Impact of the aging of a photovoltaic module on the performance of a grid-connected system. Photovoltaic Energy. 2018;174:445-454.

[21] Lu X, Lin P, Cheng S. Fault diagnosis for photovoltaic array based on convolutional neural network and electrical time series graph. Energy Conversion and Management. 2019;196:950-965.

[22] Cibira G. Relations among photovoltaic cell electrical parameters. Applied Surface Science. 2018;461:102-107.

[23] Al Essa MJM. Home energy management of thermostatically controlled loads and photovoltaic-battery systems. Energy. 2019;176:742-752.

[24] Yin E, Li Q, Xuan Y. Experimental optimization of operating conditions for concentrating photovoltaic-thermoelectric hybrid system. Journal of Power Sources. 2019;422:25-32.

[25] Jaszczur M, Hassan Q, Styszko K. Impact of dust and temperature on energy conversion process in photovoltaic module. Thermal Science. 2019;23(4):1199-1210.

[26] Lay-Ekuakille A, Ciaccioli A, Griffo G. Effects of dust on photovoltaic measurements: A comparative study. Measurement. 2019;113:181-188.

[27] Amber KP, Hussain I, Kousar A. A self-cleaning device for pole mounted solar photovoltaic installations. Thermal Science. 2019;23(2A):739-749.

[28] Bliss M, Betts T, Gottschalg R. Interlaboratory comparison of short-circuit current versus irradiance linearity measurements of photovoltaic devices. Photovoltaic Energy. 2019;182:256-263.

[29] Dubard J, Filtz JR, Cassagne V, Legrain P. Photovoltaic module performance measurements traceability: Uncertainties survey. Measurement. 2014;51:451-456.

[30] Senol MA. Performance analysis of three port full bridge converter for hybrid photovoltaic/battery management system. Thermal Science. 2019;23:79-89.

[31] Lewicki W. The case study of the impact of the costs of operational repairs of cars on the development of electromobility in Poland. The Archives of Automotive Engineering - Archiwum Motoryzacji. 2017;78(4):107-116.

[32] Varecha D, Kohar R, Brumercik F. AGV Brake System Simulation. LOGI - Scientific Journal on Transport and Logistics. 2019;1:1-9.

[33] Janicki A. Enhancing Electricity Meters with Smart Functionality Using Metering System with Optical Sensors. Proceedings ALLSENSORS. 2019.

[34] https://onemeter.com/pl/ [access 2019.07.09]

[35] http://solsum.pl [access 2019.07.09] 